\title{
АНОМАЛИИ КИНЕТИКИ НАБУХАНИЯ ЦИКЛОЦЕПНОГО СОПОЛИМЕРА ДИМЕТИЛДИАЛЛИЛАММОНИЙ ХЛОРИДА С АКРИЛАМИДОМ В ВОДЕ
}

\author{
И.М. Борисов, Р. С. Лукша, С. Т. Рашидова, Т. А. Агеева
}

\begin{abstract}
ИВАН МИХАЙЛОВИЧ БОРИСОВ - доктор химических наук, профессор, заведуюший кафедрой химии ФГБОУ ВО «Башкирский государственный педагогический университет им. М. Акмулль». Область научных интересов: Кинетика, окисление, органические сульфиды, межфазный катализ, суперабсорбенты, фазовые равновесия. Тел.: +7 (347) 273-02-90.E-mail: borisovim@yandex.ru.
\end{abstract}

РИМА СЕРГЕЕВНА ЛУКША- ассистент кафедры химии ФГБОУ ВО «Башкирский государственный педагогический университет им. М. Акмулльl». Область научных интересов: полимеры, гидрогели, сополимеризация, кинетика процессов абсорбчии и десорбиии. E-mail: luksha90@mail.ru.

САЖИДА ТАГАЕВНА РАШИДОВА - кандидат химических наук, дочент кафедры химии ФГБОУ ВО «Башкирский государственный педагогический университет им. М. Акмулльл». Область научных интересов: Полимеры, металлопорфирины, физико-химические свойства.E-mail: tagaеvna@bk.ru.

ТАТЬЯНА АРСЕНЬЕВНА АГЕЕВА - кандидат химических наук, доиент кафедры Химии и технологии высокомолекулярных соединений ФГБОУ ВО «Ивановского государственного химико-технологического университета». Область научных интересов: синтез и исследование порфиринсодержащих полимеров и новых функциональных материаловна их основе. E-mail: tageeva@isuct.ru.

450008, Башкортостан, г.Уфа, ул. Октябрьской револющчи, 3-а, ФГБОУ ВО «БГПУ им. М. Акмулльз».

153000, г. Иваново, пр. Шереметевский, 7, ФГБОУ ВО ИГХТУ.

В работе представлены результаты исследований набухания циклоцепного сополимера $N, N$-диметил$N, N-$ иаллиламмоний хлорида с акриламидом в воде. При исследовании кинетики этого проиесса наблюдается аномальный, двухстадийный процесс сорбиии. Величина степени набухания зависит от состава сополимера, гидратных чисел полярных групп полимера, объема воды, взятой для набухания, поверхности образиов и от структурных изменений, происходящих при поглощении больших количеств водьл.

Показано, что максимально возможная влагоемкость сополимера диметилдиаллиламмоний хлорида и акриламида возрастает с увеличением относительного объема воды и удельной поверхности гидрогеля. Это необычное свойство объяснено на основе двухступенчатой схемы водопоглощения, включающей равновесные стадии гидратаиии водорастворимых макромолекул сополимера и последующей абсорбиии части гидратированной воды нерастворимой фракиией гидрогеля. Закономерности поглощения воды рассмотрены во взаимосвязи с физическими параметрами: дивергенцией тензора напряжения Коши на граниие вода - гидрогель, дивергенщией полей векторов движения воды вглубь полимерной матриць и векторов изменения объема сополимера, плотностью потока диффузии воды, проницаемостью гидрогеля, условиями механического равновесия.

Ключевые слова: Сополимер N,N-диметил-N,N-диаллиламмоний хлорида с акриламидом, синтез, кинетика набухания, гидрогель, абсорбция воды. 


\title{
ANOMALIES IN THE KINETICS OF SWELLING OF THE CYCLIC CHAIN COPOLYMER OF DIMETHYLDIALLYLAMMONIUM CHLORIDE WITH ACRYLAMIDE IN WATER
}

\author{
I. M. Borisov, R. S. Luksha, S. T. Rashidova, T.A. Ageeva \\ 3-a, ul. Oktyabrskoj revoljucii, Ufa, 450008. Bashkir State Pedagogical University n. a. M. Akmulla. \\ 7, Sheremetevsky av., Ivanovo, 153000. Ivanovo State University of Chemistry and Technology.
}

The paper presents the results of studies of the swelling of the cyclic chain copolymer of $N, N$-dimethyl-N, $\mathrm{N}$-diallylammonium chloride with acrylamide in water. When studying the kinetics of this process, an abnormal, two-stage sorption process is observed. The degree of swelling depends on the composition of the copolymer, the hydration numbers of the polar groups of the polymer, the volume of water taken for swelling, the surface of the samples and the structural changes that occur when large amounts of water are absorbed.

It was shown that the maximum possible moisture capacity of the copolymer of dimethyldiallylammonium chloride and acrylamide increases with an increase in the relative volume of water and the specific surface of the hydrogel. This unusual property is explained on the basis of a two-stage water absorption scheme, which includes the equilibrium stages of hydration of water-soluble macromolecules of the copolymer and subsequent absorption of part of the hydrated water by the insoluble fraction of the hydrogel. The patterns of water absorption are considered in relation to physical parameters: the divergence of the Cauchy stress tensor at the waterhydrogel interface, the divergence of the fields of the vectors of movement of water deep into the polymer matrix and the vectors of change in the volume of the copolymer, the diffusion flux density of water, the permeability of the hydrogel, and the conditions of mechanical equilibrium.

Key words: N, N-dimethyl-N, N-diallylammonium chloride copolymer with acrylamide, synthesis, swelling kinetics, hydrogel, water absorption.

Уникальная способность гидрогелей поглощать и удерживать значительный объем воды, многократно превышающий объем исходного полимера, широко используется при осушке сильно обводненной нефти $[1,2]$, для удержания влаги в почвах [3, 4], при производстве предметов санитарно-гигиенического назначения $[5,6]$, в качестве коагулянтов, флокулянтов [7] и других областях. Все больший интерес вызывают ионогенные сополимеры на основе N,N-диметил-N,Nдиаллиламмоний хлорида, который вносит заряд непосредственно в основную макромолекулярную цепь сополимера и тем самым в значительной мере изменяет его свойства $[7,8]$. Одной из важнейших характеристик таких сополимеров является способность поглощать воду и удерживать ее в течение длительного времени. Сополимеры N,Nдиметил-N,N-диаллиламмоний хлорида с акриламидом представляют собой сшитые сополимеры, которые набухают в водных растворах и образуют полимерные гели.

Однако, имеющиеся в настоящее время в научной литературе теоретические и экспериментальные исследования не позволяют в полной мере раскрыть механизм водопоглощения гидрогелями и сущность физических факторов, оказывающих влияние на процесс водопоглощения.
Кроме того, данные по набуханию полимеров позволяют судить о структурных изменениях, протекающих в них в процессе поглощения воды.

В связи с этим целью данной работы явилось исследование влияния относительного объема воды, удельной поверхности гидрогеля и условий механического равновесия на кинетические закономерности поглощения воды сополимером диметилдиаллиламмоний хлорида (ДМДААХ) и акриламида (АА).

\section{Экспериментальная часть}

Сополимер $\mathrm{N}, \mathrm{N}$-диметил-N,N-диаллиламмоний хлорида с акриламидом получали в две стадии, предварительно проводили олигомеризацию ДМДААХ марки «ч» в количестве 0,034 моля в $50 \%$ водном растворе при $40{ }^{\circ} \mathrm{C}$. В качестве инициатора применяли персульфат аммония (ПСА) марки «хч» $\left(3,9 \cdot 10^{-6}\right.$ моля). Длительность процесса олигомеризации составляла 24 часа. К полученному олигомеру добавляли 0,017 моля ДМДААХ и 0,018 моля акриламида марки «хч» и $3,9 \cdot 10^{-4}$ моля ПСА, реакционную смесь нагревали при $40{ }^{\circ} \mathrm{C}$ в течение 0,5-8 часов. В конце процесса сополимеризации наблюдали повышение температуры и вязкости образующегося сополимера. Продукт 
реакции промывали дистиллированной водой для удаления остатков сомономеров и зольфракций, высушивали при $25{ }^{\circ} \mathrm{C}$ под вакуумом до постоянной массы.

Образцы гидрогелей получали при варьировании мольного соотношения сомономеров, температуры и скорости инициирования, принимая ее равной скорости распада ПСА [9] с вероятностью выхода радикалов в объем е $=0.5$.

Кинетику набухания сополимера изучали при $20{ }^{\circ} \mathrm{C}$ гравиметрическим методом. Степень набухания $(\alpha)$ рассчитывали по формуле:

$$
\alpha=\left(\mathrm{m}_{\mathrm{t}}-\mathrm{m}_{\mathrm{o}}\right) / \mathrm{m}_{\mathrm{o}}
$$

где $\mathrm{m}_{\mathrm{o}}$ и $\mathrm{m}_{\mathrm{t}}$ - масса исходного и набухшего гидрогеля в момент времени $\mathrm{t}$.

Степень набухания определяется химическим строением полимера и природой растворителя, сродством между ними, частотой пространственной сетки полимера и другими факторами. Химическое строение полученного сополимера ДМДА$\mathrm{AX}$ и AА зависит от природы и соотношения исходных мономеров и от условий проведения сополимеризации.

\section{Результаты и их обсуждение}

Известно, что на основе диаллильных производных четвертичного аммония можно синтезировать полимеры с циклами в цепи [2]. Процесс радикальной полимеризации ДМДААХ и его сополимеризации с акриламидом приводит к образованию циклоцепного линейного полимера и сополимера соответственно [3]. Получение сополимера может быть представлено схемой (1).

Радикал, образующийся при термическом распаде персульфата аммония (R), может присоединиться к молекуле диаллилового мономера с образованием другого радикала (I). В дальнейшем в результате внутримолекулярного роста цепи происходит образование пятичленных циклических структур в циклолинейных цепях поли-N,Nдиметил-N,N-диаллиламмоний хлорида.

Образование радикалов (II), по мнению авторов [10], следует из метода спектроскопии ЯМР ${ }^{13} \mathrm{C}$ целого ряда поличетвертичных солей семейства поли-N,N-диметил-N,N-диаллиламмоний га- логенидов. Этими авторами показано, что для всех синтезированных поличетвертичных солей образующиеся при полимеризации макромолекулы независимо от исходной концентрации мономера, природы N-алкильного заместителя и противоиона, строения растворителя содержат только пятичленные циклические фрагменты в циклолинейных цепях. Учитывая вышеизложенное, строение образующегося олигомера N,N-диметил-N,Nдиаллиламмоний хлорида (без описания стадий обрыва) может быть записано в следующем виде:<smiles>[R]CC1C[N+](C)(C)CC1CCCC1C[N+](C)(C)CC1C</smiles>

Сополимеризация диметилдиаллиламмоний хлорида и акриламида в водном растворе при $35^{\circ} \mathrm{C}$ позволила получить сополимер и определить константы сополимеризации, которые равны $\mathrm{r}_{1}=0,174$, $\mathrm{r}_{2}=6,87$ [11]. На основании численных значений $\mathrm{r}_{1}$ и $\mathrm{r}_{2}$ и поскольку $\mathrm{r}_{1}<1$, a $\mathrm{r}_{2}>1$, можно заключить, что при любом составе мономерной смеси сополимер будет богаче вторым компонентом, чем исходная смесь.

В данной работе для получения сополимера применяли не только ДМДААХ и акриламид, но и предварительно полученный олигомер диметилдиаллиламмоний хлорида. Сополимеризация олигомера с добавлением обоих мономеров (ДМДААХ и АА) позволила получить сополимер (III).<smiles>CCCCCCCC(C)C(N)=O</smiles>

(III)

Можно полагать, что и в этом случае сополимер (III) будет содержать большее число звеньев акриламида, чем в исходной смеси, используемой для проведения синтеза.
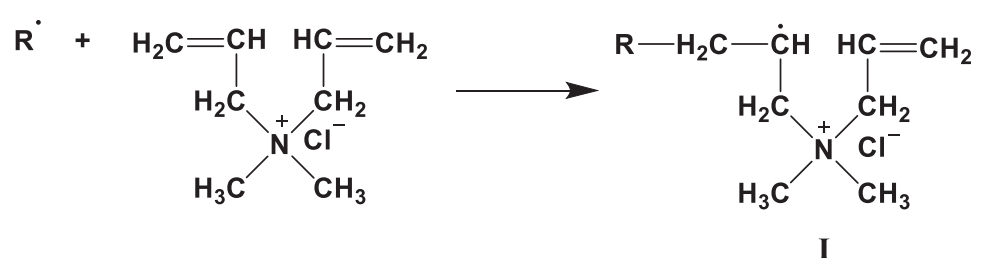

I

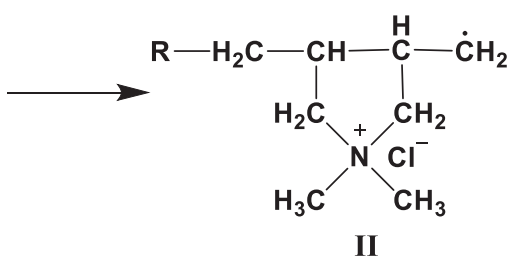


Дополнительным подтверждением этого могут служить результаты работы [8], в которой сополимер получали из макромономера поли-(N,Nдиметил-N,N-диаллиламмоний хлорида) с акриламидом, установленные в этом случае константы сополимеризации были: $\mathrm{r}_{1}=0,057, \mathrm{r}_{2}=1,57$.

Наличие звеньев акриламида в составе сополимера должно изменить сорбционные свойства по отношению к воде в связи с более высокими гидратными числами амидной группы по сравнению с другими группами сополимера [12].

Образующийся в результате циклополимеризации и сополимеризации сополимер диметилдиаллиламмоний хлорида с акриламидом имеет некоторую долю сополимера трехмерного сетчатого строения. Образование сшивок часто наблюдается при циклополимеризации [13].

Набухание циклоцепного сополимера диметилдиаллиламмоний хлорида с акриламидом изучали при $20{ }^{\circ} \mathrm{C}$ путем периодического взвешивания его после выдерживания в воде. Масса исходного сополимера составляла 0,2 г, объем воды, в котором происходило набухание, изменялся от 100 до 500 мл. Полученные кинетические кривые набухания в воде приведены на рис. 1.

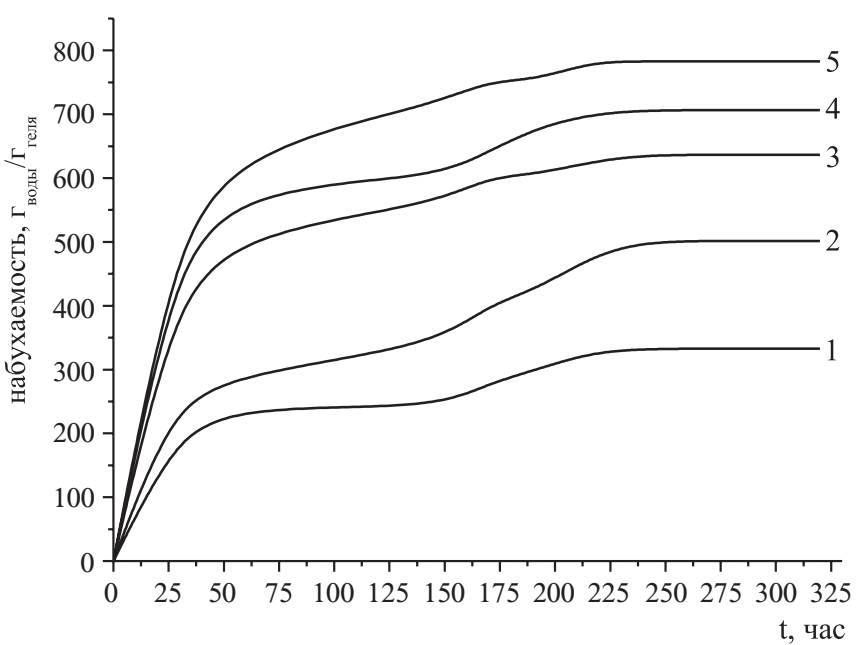

Рис. 1. Кинетические кривые водопоглощения при варьировании объемной доли воды

$$
T=20^{\circ} \mathrm{C}, \text { тгидрогеля }=0,2 \text { г. }
$$

Объем воды: 1 - 100 мл, $2-200$ мл, $3-300$ мл,

$$
4-400 \text { мл, } 5-500 \text { мл }
$$

Общепринято считать, что поглощение воды гидрогелями - это сложный процесс, зависящий от различных физических и химических факторов. В серии работ [14-19] дано обоснование разных физических моделей водопоглощения гидрогелем и предложены математические уравнения, описывающие этот процесс. Согласно представле- ниям авторов этих работ, плотность диффузионного потока воды относительно полимерной матрицы описывается следующими формулами:

$$
\begin{aligned}
& j=-n_{l} K \nabla \mu \\
& j=-\phi_{I} K \nabla \Pi \\
& j=n_{I}\left(V_{1}-V_{2}\right)
\end{aligned}
$$

где $n_{1}$ - мольная плотность (концентрация) воды; К - коэффициент проницаемости гидрогеля;

$\nabla \mu=\frac{\partial \mu}{\partial x}+\frac{\partial \mu}{\partial y}+\frac{\partial \mu}{\partial z}-$ дивергенция химического потенциала, описывает изменение химического потенциала воды в объеме полимера вдоль осей $\mathrm{x}$, $\mathrm{y}, \mathrm{z}$ декартовых координат; $V_{1}$ и $V_{2}-$ поле векторов скоростей движения воды и изменения объема гидрогеля, соответственно; $\nabla П$ - дивергенция осмотического тензора напряжений, характеризует условие механического равновесия в объеме гидрогеля; $\phi_{1}-$ объемная доля воды в исследуемой системе.

Согласно формулам (2)-(4) плотность диффузионного потока пропорциональна количеству воды, находящейся в контакте с гидрогелем. Действительно, количество поглощенной воды $\left(\Delta \mathrm{m}_{\text {водь }}\right)$ за единицу времени $(\Delta t)$, т.е. поток массы воды $\mathrm{I}=\Delta \mathrm{m}_{\text {воды }} / \Delta \mathrm{t}$, возрастает с увеличением объема изначально взятой воды при постоянстве массы гидрогеля (рис. 1).

Из рисунка 1 видно, что независимо от количества воды, в котором происходило набухание геля сополимера, характер кинетических кривых является однотипным. В начальный период набухания наблюдается линейная зависимость степени набухания от времени, а потом происходит медленное повышение количества поглощенной воды и в дальнейшем устанавливается состояние, близкое к равновесию, которое характеризуется равновесной степенью набухания $\alpha_{\max }$. Кинетические кривые набухания сополимера в воде являются аномальными, наблюдается процесс двухстадийной сорбции, хотя минимумы и максимумы на кривых выражены не очень четко. Необходимо отметить то, что максимальная степень набухания геля достаточно высокая при всех объемах воды, взятой при проведении эксперимента: 1 г геля способен поглощать от 300 до 780 г воды.

Важной характеристикой сорбционных свойств полимеров являются гидратные числа различных функциональных групп Ван Кревелена [12]. Они успешно используются многими авторами для объяснения массопереноса в различных полимерных системах [20]. 
Мольное содержание воды в полимерах на одну полярную группу при $25{ }^{\circ} \mathrm{C}$ и различной относительной влажности $(\mathrm{P} / \mathrm{P})$

\begin{tabular}{|c|c|c|c|c|c|}
\hline \multirow{2}{*}{ Группа } & \multicolumn{5}{|c|}{$\mathbf{P} / \mathbf{P}_{\mathrm{s}}$} \\
\hline & 0,3 & 0,5 & 0,7 & 0,9 & 1,0 \\
\hline$-\mathrm{CH}_{3},-\mathrm{CH}_{2}-$ & $1,5 \cdot 10^{-5}$ & $2,5 \cdot 10^{-5}$ & $3,3 \cdot 10^{-5}$ & $4,5 \cdot 10^{-5}$ & $5 \cdot 10^{-5}$ \\
\hline$-\underset{1}{\mathrm{C}} \mathrm{H}$ & 0,001 & 0,002 & 0,003 & 0,004 & 0,005 \\
\hline$-\mathrm{NH}_{2}$ & 0,35 & 0,5 & 0,75 & 1,5 & 2 \\
\hline$-\mathrm{NH}_{3}^{+}$ & - & - & 2,8 & 5,3 & 2 \\
\hline$-\mathrm{COOH}$ & 0,2 & 0,3 & 0,6 & 1,0 & - \\
\hline$-\underset{\mathrm{O}}{\mathrm{C}}-\mathrm{NH}-$ & 0,35 & 0,5 & 0,75 & 1,5 & 2 \\
\hline$-\mathrm{Cl}$ & 0,003 & 0,006 & 0,015 & 0,06 & 0,1 \\
\hline
\end{tabular}

Значения гидратных чисел групп, которые входят в состав исследованного сополимера (за исключением $\left.-\stackrel{+}{+}-\mathrm{Cl}^{-}\right)$, приведены в таблице 1 [12].

Приведенные в таблице 2 данные показывают, что сорбционная способность амидной группы на несколько порядков выше, чем для других групп, имеющихся в сополимере. Сополимериза-

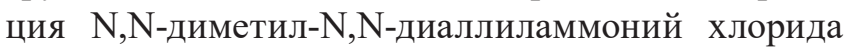
с акриламидом способствует росту способности сополимера поглощать и удерживать воду. Такой рост обусловлен как обогащением сополимера звеньями акриламида, так и более высокими гидратными числами амидной группы.

Наличие ионогенных групп в пятичленных циклических фрагментах в цепи сополимера, способность амидной группы сополимера участвовать в образовании водородной связи с молекулами воды за счет неподеленной пары электронов на атоме азота могут оказывать большое влияние на процесс поглощения воды приводя к увеличению сорбционной способности.

Образование ассоциатов молекул воды как между молекулами воды, так и с макромолекулами, должно приводить к снижению коэффициентов диффузии по сравнению со свободными молекулами воды.

Можно полагать, что большие объемы поглощенной гелем воды могут пластифицировать матрицу сополимера и тем самым ускорять процесс переноса воды в гель благодаря увеличению коэффициента диффузии при пластификации.

Аномальный характер кинетических кривых набухания, абсолютные, достаточно высокие величины $\alpha_{\max }$, особенно при увеличении объема воды, взятой для набухания, позволяют предположить, что под влиянием сорбируемой воды может про- исходить аморфизация кристаллических областей сополимера. Увеличение аморфной фазы приводит как к росту сорбционной способности, так и диффузии молекул воды, при этом полярные группы сополимера, участвующие в сорбции, становятся более доступными.

Под влиянием больших количеств воды, поглощенной гелем, могут возникать внутренние напряжения, появляется напряженно-деформированное состояние сополимера, в набухшем геле образуются микропустоты, может появиться пористость [14], которая способствует диффузии воды [21].

Возможно, всеми этими факторами можно объяснить рост степени набухания сополимера с увеличением объема воды, используемой в качестве среды набухания.

В данной работе было исследовано влияние величины поверхности контакта гидрогеля и воды на процесс водопоглощения при постоянной массе сополимера, равной 0,2 г. Изменение поверхности образцов достигалось получением пластин различной толщины. Отношение площади циклоцепного сополимера к его массе изменялось в пределах от 0,5 до $3,0 \mathrm{Mм}^{2} /$ г.

Полученные кинетические кривые водопоглощения сополимера ДМДААХ и АА в воде (рис. 2) также являются аномальными, двухстадийными, значения равновесной степени набухания зависят от величины поверхности образцов (табл. 2).

Зависимость степени набухания от толщины пластины гидрогеля служит подтверждением аномальной сорбции и диффузии, особенно в начальный период тонкий образец может сорбировать более значительные количества сорбата, чем толстый. Вероятно, это связано с разными скоро- 


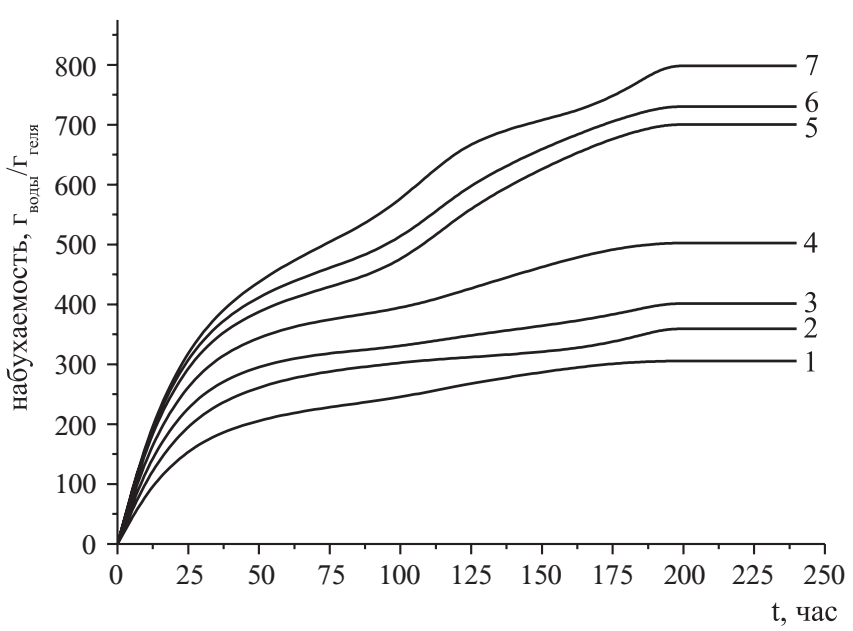

Рис. 2. Кинетические кривые водопоглощения при варьировании площади контакта воды и гидрогеля

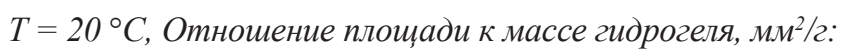
$1-0,5 ; 2-1,2 ; 3-1,3 ; 4-1,7 ; 5-2,0 ; 6-2,2 ; 7-3,0$

Таблиия 2

Степень набухания циклоцепного сополимера диметилдиаллиламмоний хлорида с акриламидом при различных поверхностях гидрогеля (S) при $20{ }^{\circ} \mathrm{C}, \mathrm{m}_{\text {геля }}=0,2$ г

\begin{tabular}{ccc}
\hline № п/п & $\mathbf{S}, \mathbf{M M}^{2} / \boldsymbol{\Gamma}$ & $\alpha_{\text {max }}, \boldsymbol{\Gamma}_{\text {воды }} / \boldsymbol{\Gamma}_{\text {геля }}$ \\
\hline 1 & 0,5 & 305 \\
2 & 1,2 & 359 \\
3 & 1,3 & 402 \\
4 & 1,7 & 501 \\
5 & 2,0 & 701 \\
6 & 2,2 & 730 \\
7 & 3,0 & 798 \\
\hline
\end{tabular}

стями изменения структуры сополимера под влиянием воды. Подобное влияние толщины пленки на сорбционный процесс наблюдалось для систем ацетат целлюлозы - хлористый метилен, полистирол - хлористый метилен [22].

Сопоставление кинетических кривых водопоглощения исследуемого сополимера при различных объемах воды, взятой в качестве среды набухания, а также при различной поверхности геля показывает, что в обоих случаях степень набухания в первом приближении можно оценить соответствующими уравнениями:

$$
\begin{aligned}
& \alpha_{\text {max }}=(4,3+1,4)+(5,9+0,9) \cdot \mathrm{V}_{\text {отн }} \\
& \alpha_{\text {max }}=(5,5+0,7)+(1+0,1) \cdot \mathrm{S}_{\text {поверх }}
\end{aligned}
$$

где

$$
\begin{aligned}
& \mathrm{V}_{\text {отн }}=\mathrm{V}_{\mathrm{H}_{2} \text { О для набухания }} / \mathrm{m}_{\text {геля }}, \text { г/л; } \\
& \mathrm{S}_{\text {поверхн }}=\mathrm{S}_{\text {геля }} / \mathrm{m}_{\text {геля }}, \mathrm{MM}^{2} / \Gamma
\end{aligned}
$$

Поскольку степень набухания сополимера зависит от объема воды, взятой в качестве среды набухания, и от поверхности образцов, в данной работе было исследовано влияние изменения условий проведения набухания. Параллельно проводились два опыта, в которых масса сополимера была одинаковой и составляла по 0,2 г, а объем воды равен 500 мл. В одном из опытов не меняли используемую для набухания воду, а во втором опыте периодически заменяли часть воды после набухания на новую порцию. Объем добавляемой воды был равен объему удаленной воды из среды набухания. Полученные в этом случае кинетические кривые водопоглощения приведены на рис. 3. Как видно из этого рисунка, при замене части воды меняется не только степень набухания сополимера, но и форма кинетической кривой, двухстадийная сорбция становится псевдонормальной.

Можно полагать, что изменения численных значений степени набухания и формы кинетической кривой, вероятно, обусловлены как химическим строением сополимера, так и взаимодействиями, протекающими между молекулами сополимера и воды, так и структурными изменениями, протекающими под влиянием новых порций воды, используемых при набухании.

Этот сополимер имеет высокое содержание катионных групп, благодаря этому может быть хорошая упорядоченность структуры, вероятно, высокая степень кристалличности. Под влиянием объ-

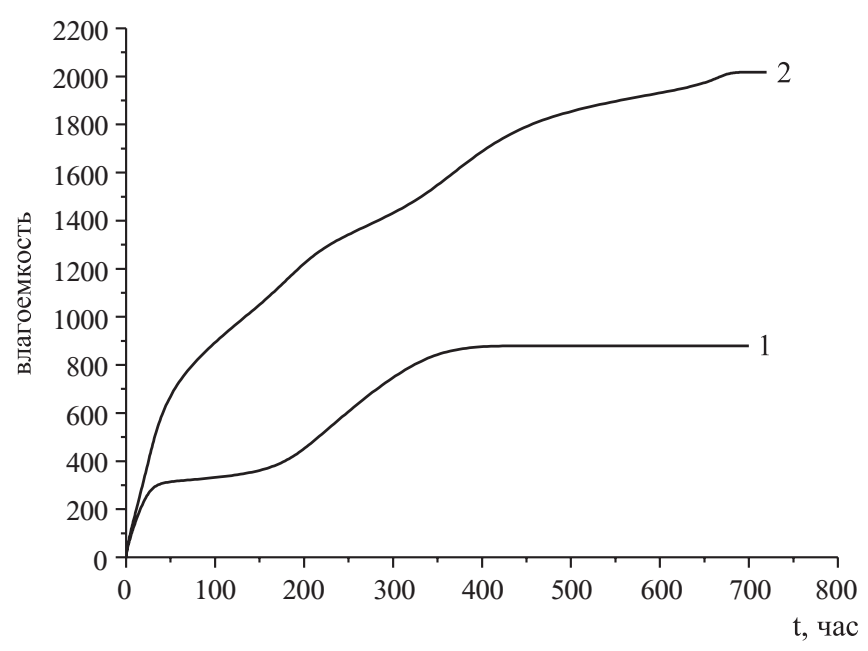

Рис. 3. Кинетика водопоглощения в условиях без замены (1) и с заменой (2) поглощаемой воды $T=20^{\circ} \mathrm{C}, m_{\text {гидрогеля }}=0,2$ г., исходный объем воды $=500 \mathrm{мл}$ 
емов воды, замена которых осуществлялась каждые сутки процесса набухания могли вымываться примеси, имеющиеся в сополимере, происходила афорфизация кристаллических областей, увеличение содержания аморфной фазы приводит к существенному росту степени набухания. Изменение степени кристалличности, вероятно, привело к смене типа сорбции, двухстадийная сорбция превратилась в псевдонормальную.

Выявленные особенности водопоглощения связаны, по нашему мнению, с надмолекулярной структурой получаемого гидрогеля. Сополимер ДМДААХ и АА в целом нерастворим в воде, но в воде из него вымываются водорастворимые макромолекулы [8], имеющие в электронных спектрах поглощения максимумы в области 240-250 нм (характерный для АА) и 890-900 нм (характерный для ДМДААХ). Нерастворимость гидрогеля в воде обеспечивают объемно-структурированные сшитые микрочастицы, образующиеся из радикальных интермедиатов - продуктов радикальных реакций (7)-(8).

Эти интермедиаты содержат три реакционных центра в виде свободной валентности на атоме углерода и двух двойных связей. Поэтому сшитый сополимер может образоваться при их рекомбинации или в ходе внедрения в растущую цепь АА.

Наличие водорастворимых и нерастворимых фракций в сополимере ДМДААХ и АА оказывает существенное влияние на состояние поверхности гидрогеля. При контакте воды с гидрогелем с его поверхности вымываются водорастворимые макромолекулы и гидрогель становится рыхлым. При периодической смене воды удаление растворимых макромолекул, очевидно, происходит в боль- шей степени и это приводит к росту коэффициента проницаемости К (формулы 2 и 3), вследствие чего возрастает скорость водопоглощения и влагоемкость гидрогеля (рис.3)

При поглощении воды гидрогелем в результате осмоса возникает осмотическое давление, которое вызывает появление поверхностных сил напряжения и растягивает гидрогель вдоль поверхности. Эти напряжения количественно описываются тензором напряжений Коши - тензором второго ранга, состоящим из девяти величин, представляющих механические напряжения в произвольной точке напряженного тела. В декартовой системе координат эти девять величин записываются в виде таблицы (матрицы), в которой по главной диагонали стоят нормальные составляющие векторов напряжений на трех взаимно перпендикулярных площадках, проходящих через рассматриваемую точку среды, а в остальных позициях - касательные компоненты векторов напряжений на этих площадках. В рассматриваемых моделях авторы [14-19] тензор напряжений Коши фактически приравнивают осмотическому тензору напряжений, который использован в формуле (3). В случае сополимера ДМДААХ и АА следует учитывать и энтропийный фактор, вызывающий дополнительные напряжения: хлорид-ионы, стремясь занять максимально возможный объем, оказывают давление на цепи макромолекул и увеличивают объем гидрогеля [5]. Поэтому в случае использованного нами гидрогеля корректнее использовать дивергенцию тензора напряжений Коши $\nabla T$ в качестве меры отклонения системы «гидрогель - вода» от механического равновесия. Диффузия воды происходит в случае $\nabla \mathrm{T} \neq 0$, если $\nabla \mathrm{T}=0$,

$$
\left(\mathrm{NH}_{4}\right)_{2} \mathrm{~S}_{2} \mathrm{O}_{8} \longrightarrow 2 \mathrm{NH}_{4}^{+}+2 \mathrm{SO}_{4}^{--}
$$<smiles></smiles><smiles>C=CC</smiles><smiles></smiles><smiles></smiles><smiles></smiles> 
то диффузия отсутствует (например, в максимально набухшем гидрогеле).

Отклонение от условия механического равновесия в набухающем гидрогеле и достижение механического равновесия в максимально набухшем гидрогеле зависит от того, насколько быстро поглощается вода и как быстро изменяется объем гидрогеля. Согласно формуле (4), плотность диффузионного потока зависит от соотношения скоростей проникновения воды в гидрогель $\mathrm{V}_{1}$ и изменения объема гидрогеля $\mathrm{V}_{2}$. Величины $\mathrm{V}_{1}$ и $\mathrm{V}_{2}$ обладают тензорными свойствами и поэтому следует учитывать дивергенцию этих двух векторных полей по всему объему сополимера.

Термодинамическое условие равновесия при поглощении воды гидрогелем зависит от величины движущей силы потока диффузии воды, т.е. разности химических потенциалов используемой («внешней») воды и «внутренней» воды в сополимере: чем больше эта разность, тем менее равновесна система «гидрогель-вода». Поток диффузии воды зависит от дивергенции химического потенциала «внутренней» воды (формула 1), т.е. от того как изменяется химический потенциал «внутренней» воды в объеме гидрогеля.

Необычные свойства гидрогеля, представленные данными рис. 1 и 2, можно объяснить на основе двухступенчатой схемы водопоглощения, включающей две равновесные стадии:

гидрогель + вода $\rightleftarrows$ гидратированные водорастворимые макромолекулы $\Longrightarrow$ нерастворимые микрочастицы с абсорбированной водой

На первой стадии водопоглощения вода расходуется на гидратацию растворимых макромолекул. Затем часть воды из гидратной оболочки абсорбируется нерастворимой фракцией сополимера ДМДААХ и АА. Увеличение относительного объема «внешней» воды смещает вправо обе равновесные стадии, что приводит к повышению максимальной влагоемкости гидрогеля (рис. 1).

С ростом площади поверхности гидрогеля, очевидно, повышается доступность нерастворимых микрочастиц сополимера ДМДААХ и АА для водопоглощения. С увеличением удельной поверхности гидрогеля, видимо, возрастает вероятность поглощения напрямую «внешней» воды нерастворимыми микрочастицами параллельно с предлагаемой схемой водопоглощения, вследствие чего возрастает максимально возможная влагоемкость образца (рис. 2).

Таким образом, полученные результаты показывают, что циклоцепной сополимер $\mathrm{N}, \mathrm{N}$-диметил$\mathrm{N}, \mathrm{N}$-диаллиламмоний хлорида с акриламидом ха- рактеризуется высокой степенью набухания в воде, на которую оказывают влияние условия проведения набухания: объем воды, взятой в качестве среды набухания, толщина образцов сополимера, а также структурные изменения сополимерной матрицы, происходящие при поглощении воды. Зависимость степени набухания от этих факторов подтверждает аномальный, двухстадийный характер сорбции воды сополимером.

Закономерности водопоглощения отражают влияние на процесс сорбции поверхностных сил на границе жидкой и твердой фаз, проницаемости гидрогеля, условия механического равновесия. Движущей силой диффузии воды в гидрогель выступает разность химических потенциалов воды в жидкой фазе и в объеме полимерной матрицы, но при этом следует учитывать поля векторов скоростей проникновения воды и изменения объема гидрогеля. Сополимер ДМДААХ и АА содержит водорастворимую и нерастворимую фракции и поэтому возможно набухание гидрогеля за счет гидратации растворимых макромолекул и абсорбции воды нерастворимыми микрочастицами.

Работа выполнена в рамках Госзадания Минобрнауки России.

\section{Литература}

1. Филлипова О.Е., Зарослов Ю.Д., Митюк Д.Ю., Гушина Ю.Ф., Арапов К.А. Башкирский хим. ж. 2010. T. 17. №3. C. 146-150.

2. Филиппова О.Е., Хохлов А.Р. Нефтехимия. 2010. T. 50. №4. C. 279-283.

3. Максимова Ю.Г., Максимов А.Ю., Демаков В.А., Будников В.И. Вестн. Пермского университета. Сер.: Биология. 2010. Т. 1. № 1. С. 45-49.

4. Наумов П.В., Щербакова Л.Ф., Околелова А.А. Изв. Нижневолжского агроуниверситетского комплекса. 2011. T. 24. №4. C. 77-81.

5. Филиппова О.Е. Природа. 2005. №8. С. 11-17.

6. Кавалерская Н.Е., Ферапонтов Н.Б. Сорбционные и хроматографические процессы. 2009. Т. 9. №3. C. $433-440$.

7. Воробьева А.И., Кутушева Э.Р., Леплянин Г.В., Гайсина Х.А., Прочухан Ю.А. Высокомолек. соед. Б, 2002, т. 44, №5. C. 868-871.

8. Калязина О.В., Мурзабекова Т.Г., Лелюх Т.Ф., Грищкова И.А. Изв. АН, сер. химическая, 2007. №3. C. $515-518$.

9. Борисов И.М., Лукша Р.С., Рашидова С.Т. Изв. АН. Сер. химическая. 2015. № 10. С. 2512-2514.

10. Wandrey Ch., Jaeger W. Acta Polymerica. 1985. V. 36. N 2. P. $100-102$.

11. Кабанов В.А., Топчиев Д.А. Высокомолек. соед. $\mathrm{A}$, 1988. Т. 30. №4. С. 675-685. 
12. Ван Кревелен. Свойства и химическое строение полимеров. М.: Химия. 1976. 415 с. (Пер. с англ. Ходжеванова. Под ред. А.Я. Малкина).

13. Киреев В.В. Высокомолекулярные соединения. М.: Высш. шк. 1992. - 512 с.

14. Денисюк Е.Я., Терешатов В.В. Высокомолек. соед. А, 2000. Т. 42, № 1. С. 71-83.

15. Денисюк Е.Я., Терешатов В.В. Высокомолек. соед. А. 2000. Т. 42. № 12. С. 2130-2136.

16. Денисюк Е.Я., Волкова Е.Р. Высокомолек. соед. А. 2003. T. 45. № 7. С. 1160-1168.

17. Денисюк Е.Я., Волкова Е.Р. Высокомолек. соед. А. 2004. Т. 46. № 5. С. 896-904.
18. Денисюк Е.Я. Высокомолек. соед. А. 2008. Т. 50. № 7. С. 1255-1268.

19. Денисюк Е.Я. Высокомолек. соед. А. 2010. Т. 52. №4. C. 634-645.

20. Чальх A.E. Диффузия в полимерных системах. М.: Химия. 1987. - 312 с.

21. Белокурова А.П., Бурмистров В.А., Щербина А.А., Зиядова T.M. Изв. вузов. Химия и хим. технология. 2011. T. 54. № 8. С. 62-65.

22. Роджерс $K$. Проблемы физики и химии твердого состояния органических соединений. М. : Мир. 1968. $-475 \mathrm{c}$. 